The Catholic University of America, Columbus School of Law

CUA Law Scholarship Repository

1990

\title{
The Ethical and Legal Implications of Hired Maternity
}

William J. Wagner

The Catholic University of America, Columbus School of Law

Follow this and additional works at: https://scholarship.law.edu/scholar

Part of the Health Law and Policy Commons

\section{Recommended Citation}

William J. Wagner, The Ethical and Legal Implications of Hired Maternity, 35 AM. J. JURIS. 187 (1990).

This Article is brought to you for free and open access by the Faculty Scholarship at CUA Law Scholarship Repository. It has been accepted for inclusion in Scholarly Articles and Other Contributions by an authorized administrator of CUA Law Scholarship Repository. For more information, please contact edinger@law.edu. 


\title{
THE ETHICAL AND LEGAL IMPLICATIONS OF HIRED MATERNITY*
}

\author{
WILlIAM JOSEPH WAgNER
}

THE FIRST INSTANCE OF HIRED maternity, a practice often misleadingly termed "surrogate motherhood," occurred in the United States at the end of the 1970's, that is, at about the time Louise Brown, the world's first "test-tube" baby, was born in England. ${ }^{1}$ But, the new reproductive arrangement touched public awareness only with the news of an event that followed nearly a decade later. On May 5, 1986, five armed law-enforcement officers appeared at a blue-collar home in Brick Township, New Jersey, to take a five-week-old infant, by all necessary force, from the arms of its lactating natural mother. ${ }^{2}$ The news reports of this preliminary step in the enforcement of a hired maternity contract against Mary Beth Whitehead and of her subsequent flight with her child brought the arrangement to the attention of the public.

In observing Whitehead's confrontation with the law, the American people were given a glimpse of the force of law directed against what is probably the most primordial of human ties: a mother's bond with her nursing child. ${ }^{3}$ To viewers conversant with the history of moral issues in American law, the vision of Whitehead's attempted flight was eerily reminiscent of Eliza's desperate flight with her child across

* Copyright 1990 William Wagner. This article grew out of an address delivered at a conference sponsored by the Pope Paul VI Institute for the Study of Human Reproduction, Omaha, Nebraska, October 28-30, 1988. I would like to thank my student research assistants, Patricia Jehle and Christine Bianchine, for their inyaluable help in the preparation of the present article.

1. Louise Brown was born on July 25, 1978. D. Demarco, In My Mother's Womb (1987), p. 143. Richard Levin of Surrogate Parenting Associates, Inc., of Louisville claims to have brokered the first "publically proclaimed case of contractual surrogate parenting" in 1979. Testimony of Richard Levin before the House Subcommittee on Transportation, Tourism, and Hazardous Materials, October 15, 1987.

2. See generally "The Fierce War of Longing Over Baby M," Washington Post, October 14, 1986, p. E4, col. 4.

3. In the pre-trial phase of litigation, the Superior Court issued an ex parte order calling for the forcible removal of the child from Mary Beth Whitehead, pending the outcome of the contract action. In the trial-level decision, the judge upheld the validity of the contract and ordered specific enforcement against Whitehead. In re Baby 'M"', 217 N.J. Super. 313, 525 A.2d 1128 (1987). 
the ice floes of the Ohio in Uncle Tom's Cabin. ${ }^{4}$ The enforcement of an alleged legal obligation appeared to violate the traditional notions of natural moral duty that had inspired Harriet Beecher Stowe. The discomfort caused by this dissonance was not to be assuaged by treating Whitehead's difficulties as the outcome of a purely private moral choice. Among the innovations of the "new reproductive technologies," hired maternity at least was not amenable to being treated under the rubric of privacy. The Whitehead case involved a public dispute between adults who hardly knew each other, over who had the right to rear a child. Whether by positive intervention or passive acquiescence, the legal system could only be implicated.

Even as "Baby M" fades from memory, lines are being drawn in a contest over the proper legislative response to hired maternity. ${ }^{5}$ This article seeks to contribute to an ethically sound public policy position on that response. Sharply defined questions of morality are rarely the only component of sound public policy, but in some matters they are inextricably one such component. Such is the case in the matter of hired maternity. In seeking to evaluate the ethics of public policy on the question, this article's focus is not the ethics of the practice of hired maternity per se, but rather the ethics of the law's response to that practice. The article, nonetheless, takes as its initial point of departure the ethics of personal decision.

An ethical assessment of personal choice provides a relevant foundation for the ethics of lawmaking in this area for several reasons. If personal choices can be shown to undermine public morality, this may be a ground for legal restriction of private activity. Conversely, where public morality is not involved arguments about the morality of the law's response are, still, easier to validate, if the morality of personal decision is clearly outlined and distinguished. Finally, the ethical horizon of personal decision, in an area as basic as the formation of familial relationships, is relevant to defining the

4. H.B. Stowe, Uncle Tom's Cabin, in Stowe, Three Novels (The Library of America ed., 1982), pp. 78-80.

5. According to the National Committee for Adoption which monitors legislative activity on this question, as of June 17,1988 , fifty-nine bills or resolutions on hired maternity had been introduced in twenty-seven states. Twenty-seven would have, to one degree or another, prohibited the practice and eighteen would essentially have permitted it. Fourteen would have created a committee to study the issue. As of June 17, 1988, at least sixteen states had enacted some form of response to the problem. National Committee for Adoption, 1988 State Legislative Activity Regarding "Surrogate Parenting" (June 17, 1988). 
vision of the good society which it should be the law's objective to further.

If an effective exploration of the ethics of the civil law's response to the practice of hired maternity is to occur, the abstract analysis of the personal ethics of hired maternity must at a certain point give way to a statement of the generic goals that ethics can be said to establish in the area for lawmaking as such. Clarity about the appropriate moral purposes of law mediates between more abstract moral principles and the concrete demands peculiar to making of laws on a concrete issue. Here, the development of such a statement is an intermediate step towards the article's ultimate goal of evaluating the soundness of available legislative alternatives for responding to hired maternity. In its final section, the article then turns to such an ethical evaluation of four legislative alternatives now emerging in the United States as possible responses to hired maternity. These include: (1) prohibition; (2) decommercialization; (3) approval with governmental validation; and (4) approval with private ordering validation.

\section{The Ethical Implications of Hired Maternity, As an Object of Personal Decision}

The morality of a practice can be assessed within any of a number of ethical frameworks. The framework, in the present article, is one of natural law reasoning grounded in the Catholic tradition. As it is avowedly Catholic, it will rely on the moral terms set out in the well publicized Vatican document, the Vatican Instruction on Respect for Human Life in Its Origin and on the Dignity of Procreation (hereinafter Vatican Instruction). ${ }^{6}$ In many ways, the article's ethical vantage is more philosophical than theological in nature. Its framework is intended to be of general application. And, its conclusions are addressed to all in the political community.

The Vatican Instruction employs three separate but complementary moral terms, in its response to hired maternity. It concludes that a

6. Congregation for the Doctrine of the Faith, Instruction on Respect for Human life in Its Origin and on the Dignity of Procreation: Replies to Certain Questions of the Day, reprinted in Pope John XXIII Medical-Moral Research and Education Center, Ethics \& Medics (Supp. April 1987), p. 20 [hereinafter Vatican Instruction]. The Vatican Instruction has a certain extrinsic authority for Catholics, as an expression of the teaching office of the Church. Its content is recognized as an authentic, if limited, expression of the Catholic moral tradition and as such has a certain intrinsic persuasiveness. For both reasons, it is a convenient point of departure for articulating a Catholic response to the new reproductive technologies. 
personal decision to participate in hired maternity cannot be morally sanctioned, because it is violative of (1) certain basic goods, (2) certain essential personal duties, and (3) certain essential rights of others. ${ }^{7}$ The goods implicated include the "unity of marriage" and the "dignity of the procreation of the human person." compromised are the mother's duty to her child ("maternal love"); her duty of fidelity to her spouse ("conjugal fidelity"), and her duty to her own integral fulfillment ("responsible motherhood"). 9 The rights violated include the child's "right . . . to be conceived, carried in the womb, brought in the world and brought up by his parents"'10 and the family's right not to be divided "between the physical, psychological and moral elements which constitute [it]." "1

The Vatican Instruction appears to focus exclusively on the choices of the woman who decides to alienate her maternity. ${ }^{12}$ The woman's decision, in a sense, serves to make the arrangement possible, so that this focus is not entirely inappropriate. The plight of the gestational mother ought not to be romanticized. At the same time, no framework for evaluating the morality of personal decision in the context of hired maternity can be considered complete unless it allows for ethical evaluation of the choices of the genetic father who conceives a child in a hired maternity arrangement, or unless it permits similar evaluation of the decisions of the commissioning party who has no genetic relationship to the prospective child but who orchestrates the conception through the acquisition of gamete(s) from third-party donor(s).

7. The conceptual division among goods, duties, and rights, which this article relies upon is implicit rather than explicit in the Vatican Instruction. The Vatican Instruction's rather terse statement on hired maternity reads, in its entirety, as follows:

Is "Surrogate" Motherhood Morally Licit?-No, for the same reasons which lead one to reject heterologous artificial fertilization: for it is contrary to the unity of marriage and to the dignity of the procreation of the human person. Surrogate Motherhood represents an objective failure to meet the obligations of maternal love, of conjugal fidelity and of responsible motherhood; it of fends the dignity and the right of the child to be conceived, carried in the womb, brought into the world, and brought up by his own parents; it sets up, to the detriment of families, a division between the physical, psychological and moral elements which constitute those families.

Vatican Instruction, p. 20.

8. Ibid.

9. Ibid.

10. Ibid.

11. Ibid.

12. The Vatican Instruction refers only to violations of "obligations of maternal love," omitting reference to parallel obligations of paternal care. Ibid. 
The culpability of the commissioning party, whether the genetic father or someone else, may be compounded by an object that is not within the intention of the natural mother at all, and, thus, is not within the framework of moral analysis expressly contemplated by the Vatican Instruction. The commissioning party may intend to use and, perhaps, even to coerce the mother, in a manner violative of her dignity as a human person. My frame of reference for evaluating the ethics of hired maternity, unlike the Vatican Instruction, extends to this latter dimension of the choices of the genetic father or other commissioning party.

\section{Hired Maternity Violates Basic Human Goods}

\section{THE UNITY OF MARRIAGE}

Assuming that the commissioning party is the genetic father and is married to another woman, the practice of hired maternity violates the unity of his marriage, since, in relation to the commissioning couple, the result is genetically asymmetrical reproduction. ${ }^{13}$ If the gestational mother is married to another man, then the arrangement violates the unity of her marriage for the same reason. Her action is objectionable because she actualizes her procreative power to create a child benefitting a marriage other than her own, his because he diverts the resources of his household to rearing a child whom he has deliberately chosen to conceive with one other than his wife.

Proponents of hired maternity assert that there is no violation of the respective marriages of the two individuals who contribute genetically to the conception of the child, because they share no venereal pleasure. This argument misconstrues the opprobrium historically attached to adultery in nearly all cultures. If anything, illicit sharing in extramarital pleasure has been a secondary ground

13. The concept of marriage as a union of "one flesh" derives from the Genesis account of creation (Gen 2:24) and is appropriated by the New Testament (Matthew 19:4-6; Mark 10:5-8; Ephesians 5:31). The concept is a standard point of reference in magisterial teaching on Christian marriage. E.g., Vatican Instruction, p. 18. The concept of matrimony operative in American law since the advent of no-fault divorce departs considerably from this ideal. See H. Clark, 1 The Law of Domestic Relations in the United States (1987), pp. 68-81 [hereinafter The Law of Domestic Relations]. Nonetheless, the concept of marriage within the American legal system remains one founded on a morally distinctive, presumptively exclusive community of interest, with roots in the Western and Christian traditions. Griswold v. Connecticut, 381 U.S. 479 (1965). It is with this broader civil law notion of marriage, along with its concomitant idea of family that hired maternity is in irreconcilable conflict. 
for condemning adultery. The evil generally seen as primary has been illegitimate births whether within or outside the family unit, depriving the innocent spouse of the exclusive opportunity to procreate with his or her partner and, in the case of adultery by the wife, of certainty as to which offspring are his.

Further, to the real extent that adultery is a betrayal of the affective as opposed to the procreative dimension of marital unity, hired maternity entails, in a certain sense, if not a pleasure bond, a bodily union between the gestational mother and the genetic father who has commissioned the pregnancy. Through the offices of a physician, his semen enters her body, and through it she may share, for instance, any venereal diseases from which he suffers. Women have become infected with the HIV virus through artificial insemination by donor. ${ }^{14}$ Inasmuch as she shares this communication and risk with a man not her husband, the gestational mother can be said to violate the unity of her marriage.

Before leaving the question of marital unity, it will be noted that the violations of the unity of marriage implicit in hired maternity have a novel feature. Persons can commit them without contributing in any bodily way to the reproductive process. Parties commissioning a hired maternity conception without contributing genetically to the conception do so. In such cases, it would seem that the unity of marriage is compromised in the more profound way because of the greater disintegration reflected in the choice. It also bears stating that every kind of violation of marital unity that the practice of hired maternity makes possible is compounded, when money, either as means or end, facilitates or induces the violation.

\section{The Dignity of the Procreation of the Human Person}

According to Catholic moral teaching and to the natural law reasoning espoused here, human reproduction must meet at least three requirements if it is to accord with the dignity of the human person. The party who intends to reproduce must be willing to treat the person procreated as an "end in him or herself" from the moment

14. Under present modes of artificial insemination by donor (AID), infection by venereal disease is a distinct possibility. This danger is the more menacing in view of the contemporary epidemic of acquired immune deficiency syndrome. "Artificial Insemination and AIDS," Washington Post, Health Magazine., Jan. 5, 1988, p. 17, col. 1 (Four Australian women infected with AIDS virus through AID). See generally Mascola \& Guinan, "Screening to Reduce Transmission of Sexually Transmitted Diseases in Semen Used for Artificial Insemination," 314 New Eng. J. Med. (1986), p. 1354. 
that the possibility of procreation comes into view. ${ }^{15}$ The party reproducing must be willing to assume a relationship of unconditional parental loyalty to the person being procreated once that person's life is conceived. ${ }^{16}$ And, he or she must act within a relationship with the one who provides the second gamete necessary for conception, that adequately respects that person's dignity, which is to say, within the marriage relationship. ${ }^{17}$ Hired maternity does not satisfy any of these three requirements.

The requirement that the child conceived always be viewed as "an end in him or herself" is violated when the natural mother makes of the child an instrument to obtaining a medium of exchange not even itself a basic good, i.e., money. Reciprocally, where one views the transaction from the perspective of the commissioning couple whose end it is to obtain the child, the conclusion remains unavoidable that the child is "purchased" and a monetary value placed on a human person. From this aspect, the child conceived is treated also as an object rather than as an "end in him or herself."

Some argue that the alienation of motherhood in "surrogacy" arrangements is not morally wrong where the act is truly donative, because uncompensated beyond basic expenses and motivated by altruism. This argument is not sound. Even on the terms stipulated, the mother assumes a kind of dominion over the incipient human person for the sake of the good of third persons (i.e., the commissioning couple). The child is still being treated as a means rather than as the end that morality insists that he or she always remain. The fact that the end is, at least, the basic good of "friendship" with a third party does not alter the intrinsic moral evil of an act that reduces the child to a means.

15. The person's status as "end in him or herself" is expressed theologically as being made "in the image of God." Vatican Instruction, p. 9. Respect to a human life is, on this basis, owed from the moment of conception. Ibid., p. 10. It is owed, in an anticipatory way, from the moment the couple contemplates the marital act, since the procreation of another being is deemed to be an intrinsic, indefeasible aspect of the meaning of sexual intercourse. Pastoral Constitution on the Church in the Modern World (Gaudium et Spes) (1965), reprinted in The Documents of Vatican II (W. Abbott \& J. Gallagher eds. 1966), p. 253, [hereinafter Pastoral Constitution] and Paul VI Humanae Vitae 60, Acta Apostolicae Sedis 481, sec. 12 pp. 488-89 (1968).

16. Procreation is understood in the Catholic tradition as more than merely transmitting life to a child, rather it is understood to mean both giving biological life to and rearing the child to maturity. Having given life to the child, the parent has the duty and the right to rear it. Pastoral Constitution, p. 254.

17. Vatican Instruction, pp. 14-15. The spouses are required to treat one another as ends-in-themselves and with unconditional loyalty, which means marriage is exclusive and indissoluble. Pastoral Constitution, p. 254. 
The second requirement established by respect for the dignity of the procreation of the human person-unconditional parental loyaltyis compatible with an intent to terminate the parental relation only where the reason is the child's best interest. Some argue that the termination of parental rights by the gestational mother in hired maternity arrangements is justified, because the voluntary termination of parental rights in cases of adoption can be justified. This analogy is misplaced. The action of a natural mother who yields her child for adoption is morally justifiable because, through contingent events over which she has failed to exercise sufficient control, she finds she cannot adequately care for her child. Relinquishment is on the ground of the child's best interest. By contrast, the termination of parental rights in hired maternity arrangements is, at best, for the sake of the third-party rather than for that of the child. As such, it violates the parent's fiduciary duty of loyalty to her offspring. Agreements to be bound in advance to deliver a child necessarily violate this principle, since the gestational mother cannot know in advance whether the commissioning couple will be fit to care for the child, as of the future delivery date. The acceptance or conferral of money as inducement to this breach of unconditional parental loyalty obviously aggravates the wrong.

The third element required by respect for the dignity of the procreation of the human person, marriage between the child's biological parents, says that the violation of the unity of marriage represented by hired maternity, discussed above, is simultaneously a violation of the dignity of the person whose procreation is in prospect. This covalence illustrates the essentially triadic nature of the relationships at the core of the family.

\section{Hired Maternity Violates Essential Moral Duties}

As the Vatican Instruction suggests, the wrongfulness of hired maternity can be further illumined by shifting the discussion from basic goods to essential duties. The wrong under discussion may, in fact, be substantially one and the same. Even so, the fuller scope and meaning of the wrong becomes clear when the matter is considered from this second aspect. From this vantage, the Vatican Instruction specifies that hired maternity compromises three sorts of duties. They are: (1) duty to child; (2) duty to spouse; and (3) duty to self. Because I wish to expand the Vatican Instruction's frame of reference to include the evaluation of the actions of commissioning parties, I shall also extend my consideration to a fourth duty: (4) duty to neighbor. 


\section{Duty to ChIID}

The offense against the good of the dignity of the procreation of the human person which hired maternity represents becomes concretely a violation of a duty to the child once the child comes into being. The Vatican Instruction rightly indicates that this duty is the very opposite of the arm's length fairness characteristic of the market place: it is the duty of unconditional love. The execution of a promised performance to deliver over a child, under a contract signed before his or her conception, is a violation of a morally prior duty to the baby. Mary Beth Whitehead's change of heart, in this respect, occurred within the locus poenitentiae. ${ }^{18}$ The gestational mother has a moral duty to resist the enforcement of the contract even after she has entered it. Such is not to say that she has a moral duty to refuse to relinquish custody of the child. The moral evaluation of a decision to relinquish custody would depend on her uncoerced judgment respecting the child's best interest at the time of its birth.

\section{DuTY To SPOUSE}

The violation of the good of marital unity which hired maternity represents, when considered from the aspect of essential duties, is seen also to entail the violation of duties owed by the participating spouse to his or her marital partner. The unilateral disposal of one's bodily powers of procreation by extramarital procreation, sterilization, or abortion generally is to wrong one's spouse, who has a morally cognizable interest in one's fertility. Where the disposal of these powers results in asymmetrical procreation, either within or outside of the family unit, the spouse, who chooses to procreate unilaterally, simply wrongs his or her partner under this general principle in one distinctive way. The duty in question can, more generally, be termed that of marital exclusivity or monogamy. Hired maternity is, in effect, a new form of polygyny or polyandry, the sort of arrangement which heretofore has been prohibited under laws against bigamy and polygamy. ${ }^{19}$

18. This concept is recognized in law in the context of the exoneration flowing from the timely abandonment of an illegal course of conduct. Town of Meredith v. Fullerton, 83 N.H. 124, 139 A. 359 (1927).

19. See generally The Law of Domestic Relations, pp. 127-35. The constitutionality of such laws was upheld in Reynolds $v$. United States, 98 U.S. (8 Otto 145) 244 (1878), but under contemporary trends it might be challenged. 


\section{Duty to SelF}

Each person has a duty to attend to his or her own integral selffulfillment. ${ }^{20}$ The actualization of the procreative powers through hired maternity violates this obligation. In this regard, the analogy which has been made between hired maternity and prostitution is apt. The gestational mother, in such arrangements, makes a choice to realize her powers of procreation in a way which leaves the outcome disintegrated from either marriage or a relationship with her child. In her experience of pregnancy and childbirth in particular, the woman is alienated from her bodily experience of union with the child developing within her, and, thus, necessarily is alienated even from an integral experience of her body: her body says the child is hers, but her intention says it is not. Her choice, like prostitution, is objectively depersonalizing and degrading. The choice of the genetic father is likewise one to procreate in a manner disintegrated from marriage, although obviously not from relationship with the child. The fact that he may be in a marriage with another woman, who is willing to assume the rearing role with him, does not change the fundamental disintegration implicit in the rejection of integral personal fulfillment entailed in his choice of extramarital generation.

\section{Duty to NeIGHBoR}

The human person owes a duty to his or her neighbor not to actualize his or her sexual and procreative powers in a manner reducing the neighbor to a means rather than an end. This principle, of generally uncontested validity with respect to the ethics of sexual pleasure, is, perhaps, less widely acknowledged as applying to the ethics of procreation. On this point, there is a definite need to supplement the perspective provided within the Vatican Instruction. In hired maternity, a woman is not treated as an end in herself, as is a wife who becomes a mother through the unitive love of her husband. Rather, she is treated as a "vessel" and as a "source" of ova. She is treated as an instrument. Inducing her consent to this role merely means eliciting from her her own participation in the violation of her integral self-fulfillment in the domain of procreation and sexuality. This serious wrong is the most public of the wrongs involved in hired maternity. It is a wrong to which the feminist

20. T. Aquinas, Summa Theologica, I.II. Q. 3, art. 1, pp. 595-96 (Eng. Dominicans trans. reprinted by Christian Classics, 1981) [hereinafter Summa Theologica]. 
critique of hired maternity is rightly sensitive. ${ }^{21}$ The wrong is only aggravated when the commissioning party induces the mother to violate her integrity in this fashion by means of monetary compensation. Such payment can be thought of as the equivalent of a bribe of an official to violate a non-defeasible duty. ${ }^{22}$ The use of the coercive power of the civil law to compel the involuntary performance of an agreement to terminate parental rights, under a hired maternity arrangement, transforms the act of merely inducing the mother to wrong herself, into what amounts to violence against the integrity of the mother's relationship with her child.

Where the commissioning party has no parental rights in relationship to the child based in genetics, the violation of the neighbor's personality whether through his or her voluntary participation or through legal coercion would seem the more culpable. In such a case, the conflict of adult interests involved does not allow itself to be viewed as one natural parent combating the other for the sake of the love of a natural child. Instead, it can be understood only as the quest for dominion over integral aspects of another's personality in order to realize an abstract personal project. On the facts of the Stern/ Whitehead dispute, the wife of the sperm donor, among the adult participants, probably stood, for this reason, in what objectively is the most questionable ethical light. ${ }^{23}$

\section{Hired Maternity Violates Essentlal Rights}

\section{The Rights of THE CHIID}

For the reasons given earlier, the practice of hired maternity violates a parental duty to the child conceived. Focusing on the wrong which either natural parent alone does to the child in this kind of arrangement does not, however, exhaust the violation which the arrangement signifies for the rights of the child. This is because

21. See generally G. Corea, The Mother Machine: Reproductive Technologies From Artificial Insemination to Artificial Wombs (1986).

22. J. Noonan, Bribes (1984), pp. 683-706.

23. The wife of the sperm donor was deliberately excluded as a party to the contract for the purpose of avoiding conflict with the New Jersey laws against child selling. But, it was apparently her reluctance to accept the risks of pregnancy that led the couple to undertake a hired maternity arrangement with Mary Beth Whitehead. Whitehead's realization that she did not wish to go through with the arrangement was triggered by the wife's attempts to control her behavior. Whitehead relates that she felt that "Elizabeth Stern was trying to take over her life." "Who Keeps 'Baby M'?', Newsweek, Jan. 19, 1987, p. 49, col. 1. 
the child has a right to more than one parent can give alone. The child has a right to a continuous relationship with a parental couple which is grounded in unconditional commitment and which issues forth in continuous personal-psychological love and nurturance. The child also has the right to experience a convergence in his or her social, genetic, and psychological identity. Hired maternity deprives the child of this holistic unity of origin and rearing. The fragmentation of the modern world has given rise to what Robert Jay Lifton has identified as a crippling neurosis caused by discontinuity and unconnectedness from elements of identity, such as those found in the natural world and in preceding human generations. ${ }^{24}$ As Leon Kass illustrates, hired maternity represents an extreme example of the modern fragmentation causing this painful psychic condition. ${ }^{25}$ Deliberately to deny a child continuity and connectedness with conception, gestation, and rearing within a unified family counts as the willing imposition of grave harm.

Proponents of the practice assert that the child does not have rights that can be violated by the arrangement, since he or she was not in being when the arrangement was agreed upon, and, indeed, but for the arrangement would never have existed. In this view, the child is better off because of the arrangement, since he or she exists only because the arrangement occurred. One flaw in this argument is that it presupposes that some net improvement in a person's general welfare can justify a deliberate violation of that person's human dignity. The argument would also serve to justify mercy killing. Another flaw in the argument is that the wrong, in the first instance, should be viewed as committed not against the child who comes to be, but against the hypothetical rights of prospective children whose procreation is in view when the arrangement is contemplated. ${ }^{26}$

\section{RIGHTS OF FAMILY}

Some have faulted the Vatican Instruction for speaking of the "rights of the family," on the ground that only individuals should

24. R. Lifton, The Life of the Self (1976) [hereinafter The Life of the Self]. Lifton's theory grows out of his work on the survivors of Hiroshima. See R. Lifton, Death in Life: Survivors of Hiroshima (1968). A well known practical application of his theory that had legal ramifications is described in K. Erikson, Everything in its Path: Destruction of Community in the Buffalo Creek Flood (1976).

25. L. Kass, Towards a More Natural Science (1985), pp. 110-15.

26. Karka, "Paradox of Future Individuals," 11 Phil. \& Pub. Aff. (1981), pp. 93, 94. 
be deemed to have rights. But, this criticism reflects an unduly individualistic and atomistic understanding of personal and social relationships. Individual identity is itself inconceivable without some definition through familial or other social relationships. Families and even voluntary associations, thus, must be viewed as having moral "rights" in an important sense. The Vatican Instruction asserts that the practice of hired maternity violates at least one such right. This is the family's right to "physical, psychological and moral" unity and integrity. ${ }^{27}$

This assertion is justified, and its importance and urgency become apparent when one notes that hired maternity severs the necessity of any link between marriage and procreative union, or between genetic and rearing parentage. ${ }^{28}$ In this regard, it exacerbates the disconnectedness and discontinuity identified by Lifton as, perhaps, the single greatest threat in our own era to human wholeness and well being. ${ }^{29}$ The harm threatened is not just for the children begotten through hired maternity, but for everyone. The practice shatters the organic meaning of "parent," "child," and "spouse," as it devalues the currency of the received language of courtship, love, and commitment, and of relations between men and women, as well as of between adults and children. Were the practice generally countenanced, it would make it more difficult to form or recognize integral family relationships, even when by the natural resiliency of human beings they appered as an option.

The ethical implications of hired maternity should be considered unremittingly negative. There is no reason to suppose the practice anything other than a regression in societal moral consciousness.

\section{A Statement of the Generic Purposes Which a Sound Ethics Prescribes for LaW Making ON THE QUestion OF HiRed Maternity}

In the Catholic view, the fullness of moral obligation is enforceable solely by God. The divine enforcement of moral norms is both omniscient and omnipotent. It is tempered by divine wisdom and mercy. As such, it largely transcends human comprehension and, only by analogy, can be considered comparable to the enforcement of human law. Within history, the Catholic tradition generally has

27. Vatican Instruction, p. 16.

28. Wagner, "The New Reproductive Technologies and the Law: A Roman Catholic Perspective," 4 J. Contemp. Health L. \& Policy (1988), p. 45.

29. The Life of the Self, supra note 24. 
assumed that such divine enforcement is operative, as one aspect of natural law, in certain natural penalties that are the intrinsic outcome of disordered conduct. ${ }^{30}$ Eschatologically, God is expected to add a final divine judgment against sinners. According to representative thinkers in the Catholic tradition such as John Courtney Murray and Thomas Aquinas, one difference between the divine enforcement of moral norms and the enforcement of such norms under human law is the circumscribed scope of human law.31 Through its sanctions, human law does not and should not attempt to enforce morality per se. It seeks only to effectuate the common good, by preserving, at a minimum, public order, public morality, and justice. ${ }^{32}$

If one is to arrive at a reliable statement of the generic goals for lawmaking that ethics establishes in the area of hired maternity arrangements, one must make clear at the outset that the eradication per se of the immoral personal choices outlined above lies outside the role of the civil law as understood within the Catholic tradition. The practice of hired maternity should be outlawed for its immorality no more than should the old Protestant Comstock laws against contraceptives be revived simply because the Church teaches that contraception is never morally admissible. ${ }^{33}$

At a certain point, however, personal moral choices have public moral implications. When this threshold is crossed, the legal response to an emerging social practice itself becomes subject to moral evaluation. For example, where the bad moral choices in hired maternity can be shown to have a notoriety that undermines the public moral health of society, the civil law may need to restrict individual freedom to pursue such choices for the sake of what may be called "public morality." On this basis, restriction on the

30. In Saint Thomas this penalty is understood in terms of a depravity of the will. Summa Theologica, I.11., Q. 91, art. 6, p. 1079. A Christian political philosopher like John Locke sees a pervasive disutility flowing from sinful action reflective of God's will to reward virtue and punish vice. The Locke Reader (J. Yolten ed. 1979), p. 191.

31. Summa Theologica I.II. Q. 95, art. 2, p. 1081; J.C. Murray, We Hold These Truths (1960), pp. 155-174 [hereinafter We Hold These Truths].

32. 7 Declaration on Religious Freedom (Dignitatis Humanae), reprinted in The Documents of Vatican II (W. Abbott and J. Gallagher eds. 1966), p. 687.

33. The original Connecticut Comstock law against contraception, which was overturned, as amended, in Griswold v. Connecticut, 381 U.S. 479 (1965), was originally 1879 Conn. Pub. Acts Ch. 78, and later Conn. Gen. Stat. Sec. 8568 (1949). Comstock also successfully lobbied the federal government for a law restricting contraception. The federal law enacted was found at 18 U.S.C. Sec. 1461-62. For a general discussion, see The Law of Domestic Relations, p. 362. For a discussion from the Catholic perspective, see We Hold These Truths, supra p. 157. 
advertisement and brokerage of hired maternity arrangements would be justified. Similarly, if it can be shown that the bad moral choices involved in this practice erode society's "public order," they may be curtailed by law. In the Catholic view and, indeed, in the AngloAmerican legal tradition, the institutions of marriage and the family are the basic building blocks of the social order, that is to say, moral realities to which fundamental reference must be made in any just allocation of societal rights and duties. ${ }^{34}$ Hired maternity impairs the order of these fundamental relationships. At a minimum, the state must, therefore, withhold its enforcement mechanism from use as an instrument effectuating such arrangements. This the law has traditionally done, by treating contracts impairing familial relationships as unenforceable and void as against public policy. ${ }^{35}$ The law of marriage and family, grounded as it is in equity rather than contract, ought to remain the exclusive legal matrix for a constitutive order of domestic relationships in the domestic sphere.

The law of marriage and family establishes certain formal requisites for recognizing de facto human sexual and procreative relationships as the basis of legally sanctioned rights and duties. De facto sexual and procreative relationships standing alone do not constitute legally cognizable marriage and family. Compliance with legal form is necessary before societal recognition through law is warranted. Yet such legal requirements may not be arbitrary. They receive their normative direction from the natural givens of genetic and sexual bonds.

Even when the civil law strikes a correct balance in this regard, social practice will remain imperfect. Experience shows that some number of couples become sexually involved outside of marriage and some number of children are born out of wedlock. Such couples and children ought to be seen as having certain legally cognizable natural rights and duties, despite the absence of compliance with legal form sufficient to create a cognizable marriage..$^{36}$ Conversely, where there has been compliance resulting in a legal marriage, the state may,

34. From the perspective of the Catholic Church, see Pastoral Constitution, pp. 257-58. For the principle in American law, see Meyer v. Nebraska, 262 U.S. 390 (1923), and Pierce v. Society of Sisters, 268 U.S. 510 (1925). An alternative way of talking about the "public order" is to refer to the minimum requisites of a "vision of the good society."

35. E. Allan Farnsworth, Contracts (1982), pp. 341-47.

36. For instance, under American constitutional law it is recognized that the illegitimate child has a right to support from his or her natural parent. Levy $v$. Louisiana, 391 U.S. 68 (1968). 
under its parens patriae power, have to disregard the integrity of the family thereby formed, for the sake of protecting unemancipated or incompetent family members from abuse or neglect. ${ }^{37}$

In the concrete situation, society can only escape from this dilemma by making a judgment about which element it is more important to stress under relevant circumstances. An integral family remains the ideal, but under the imperfect conditions of human society, a legal system may give greater weight either to compliance with legal form or to de facto sexual and procreative relationships, as it recognizes concrete claims. For example, it may give greater weight either to the presumption of legitimacy that arises from the spouses' legal marriage ceremony or to the natural rights of the genetic father, where the mother's spouse is not the genetic father. ${ }^{38}$ While there is a certain prudential latitude in deciding exactly how to strike this balance, legal form ought not to be detached from underlying givens of de facto sexual and procreative relationship, as fundamental sources of normative direction.

In the context of the new reproductive technologies generally, and of hired maternity in particular, alternative matrices have been suggested as sources of the basic normative direction in the area of domestic relations. These alternatives include: (1) the autonomous intention of the individual, under liberal individualism; and (2) positive conferral by the state, under theories giving overriding importance to the sovereign command of government. Both are currently proposed as substitutes for the normative direction, which the inherent human moral significance of sexual and procreative relationships has traditionally provided for law and social order.

In political terms, the law's response to hired maternity places at issue the natural family as a viable subsidiary unit of society, which is capable of resisting the degeneration of social life into either individualism or collectivism. If the normativity of the intrinsic structure of sex and procreation is sacrificed as the basis for formulating rules on legally cognizable marriage and domestic rights and duties, in favor of one of these stated alternatives, either the market or the state can be expected to invade the sphere of intimate human relations, ultimately at devastating human cost.

37. Under American law, a natural parent's rights may be terminated involuntarily because of unfitness or abandonment, as long as certain due process safeguards are met. Santosky v. Kramer, 455 U.S. 745, 763 (1982).

38. The Law of Domestic Relations, pp. 341-44. Compare Justice Scalia's plurality opinion with Justice Brennan's dissenting opinion in Michael $H$. and Victoria D. v. Gerald D., 160 S. Ct. 22. 
Ethically speaking, the law ought to embrace, as a fundamental goal, the protection of the integrity of marriage and family, as these basic institutions take shape within a normative matrix based on natural sexual and procreative relationships. To succeed at this, the law must do more than shelter concrete families already in being. It must also seek to protect the common pool of intangible social terms which makes the formation and survival of families possible. The law. ought to preserve the currency of genetic relatedness and covenantal commitment as societally meaningful terms, in order to permit families to be formed and to flourish. On this ground, it may prohibit commercial hired maternity which tends, in general, to "poison the well" of social interaction between men and women and parents and children.

In addition to protecting the family, the law has an equally fundamental role in upholding the moral dignity of the human person. Such recognition is a touchstone of the moral legitimacy of any government. The law ought not, therefore, to sanction the alienation of basic dimensions of personality, such as that involved in peonage, slavery, or indentured servitude ${ }^{39}$ Neither should the law allow the value of the human person directly to be assessed in dollars or otherwise quantified as expendable in a master calculus of social utility. On this basis, the law may prohibit money passing hands or the enforcement of contracts, either for custody of a child or termination of a natural parent's rights.

A respect for the family that properly balances the importance of formal legal requirements with that of the normativity of sex and procreation; a respect for the dignity of the individual person; and public morality-such are the generic goals, then, which ethics proposes for the civil law, as it responds to the practice of hired maternity. And, yet, the evaluation of particular legislative proposals in the light of these generic goals stands in need of further mediation by political prudence. According to St. Thomas, the rule of law is grounded primarily in the free and reasonable appropriation of those governed, the force of coercion being available in the marginal case to bring the bad man into compliance with external order..$^{40}$ Given the moral tenor of the particular society, the question for prudential judgment is how best to draw lines effectuating laws based both in

39. As reflected, for example, in the thirteenth amendment to the U.S. Constitution: "Neither slavery nor involuntary servitude, except as a punishment for crime whereof the party shall have been duly convicted, shall exist within the United States, or any place subject to their jurisdiction."

40. Summa Theologica, I.II. Q.96, art. 4 and 5, pp. 1019-1021. 
the objective requirements of justice and public order and in the free affirmation of the populace. The lawmaker must decide what indirect moral harms, perversely following from the pursuit of any one aspect of the good under the circumstances, may outweigh the good which legal intervention intends. He or she must also ask how the generic goals prescribed by ethics can be effectively communicated within the existing categories of the legal culture.

More concretely, the task of political prudence is to select the best means towards realizing the generic goals of lawmaking, under the conditions prevailing in a particular legal system. A number of concrete objectives present themselves in the setting of hired maternity, as possible means for realizing the relevant generic goals described above. These objectives ought to be considered in an order of descending importance in relation to two factors: the importance of the particular aspect of the societal good to be attained, and likelihood of success. In the order accordingly assigned such intermediate objectives here may be said to include:

1. Nonenforcement of hired maternity contracts upon avoidance by the gestational mother;

2. The prohibition of fees for delivering custody of an infant;

3. The prohibition of fees for terminating parental rights;

4. The parens patriae right of the state to intervene in custody allocations to safeguard the welfare of affected children;

5. The prohibition of advertising and brokerage that serves to induce participation in hired maternity arrangements;

6. The prohibition of procreation by partners who are not in a legally cognizable marriage, or at least a de facto monogamous heterosexual relationship; and

7. The prohibition of procreating or gestating a child for the purpose of yielding custody to another.

A morally sound legislative response to hired maternity will advance the generic goals set out above, but it will do so through the prudent application of some or all of these intermediate objectives, as prevailing circumstances make appropriate.

\section{Emerging Legislative Options For a Response to Hired} MATERNITY

As far as practicable, legal proposals should adopt conceptual starting points already available within existing law, especially perhaps when offered from specifically moral conviction. Recommendations for legal responses to hired maternity, which are grounded in ethics, ought inductively to seek out the foundations for an ethically sound 
approach which already may be present in the law. The New Jersey Supreme Court opinion in In re Baby $M^{41}$ represents both the most authoritative and best reasoned legal analysis on how the existing law in a typical American jurisdiction should be read to govern the practice of hired maternity. In the context at hand, therefore, the New Jersey opinion is an appropriate departure point for considering reform.

\section{IN RE BaBy M}

The New Jersey High Court ruled unenforceable the terms of the Whitehead-Stern contract providing for allocation of custody rights, and for termination of the natural mother's parental rights. ${ }^{42}$ The court concluded that the custody provision was unenforceable under the state's policy against exchanging money for the right to rear a child. The court found that such a policy derived from the New Jersey anti-baby-selling law enacted to end black-market adoption. ${ }^{43}$ It concluded that the contractual provision terminating Whitehead's parental rights was unenforceable by reason as well of a second state policy restricting the termination of parental rights to cases of prior parens patriae determination of abandonment or unfitness on the part of the natural parent. ${ }^{44}$

41. Matter of Baby "M", 109 N.J. 396 (1988).

42. 109 N.J. at $423-25,434-44$.

43. 109 N. J. at $425-44$.

44. Matter of Baby " $M$ ", 109 N.J. at 452 , n. 16. This text is important and worthy of complete citation here:

If the legislature were to enact a statute providing for enforcement of surrogacy agreements, the validity of such a statute might depend on this strength of the state interest in making it more likely that infertile couples will be able to adopt children. As a value, it is obvious that the interest is strong; but if, as plaintiffs assert, ten to fifteen percent of all couples are infertile, the interest is of enormous strength. This figure is given both by counsel for the Sterns and by the trial court [citation deleted]. We have been unable to find reliable confirmation of this statistic, however, and we are not confident of its accuracy. We note that at least one source asserts that in 1982, the rate of married couples who were both childless and infertile was only $5.8 \%$ [citation deleted].

On such quantitative differences, constitutional validity can depend, where the statute in question is justified as serving a compelling state interest. The quality of the interference with the parents' right of companionship bears on these issues: if a statute, like the surrogacy contract before us, made the consent given prior to conception irrevocable, it might be regarded as a greater interference with the fundamental right than a statute that gave effect only to a consent executed, for instance, more than 6 months after the child's birth. There is an entire spectrum of circumstances that strengthens or weakens the fundamental rights involved and a similar spectrum of state interests that justifies 
It should be apparent that the New Jersey holding satisfies a number of the intermediate objectives proposed above for a sound legal response to hired maternity. Although binding only in New Jersey, the holding will be persuasive elsewhere because of the prestige of the New Jersey Court. However, the New Jersey opinion itself gives notice that it is no ground for complacency, since it grants that the policies on which it rests can be altered by legislation. Constitutional argument may provide little brake in how far legislatures might go in this regard..$^{45}$

At present, legislative proposals are being tested before courts and legislatures around the United States which would affirm, strengthen,

or does not justify particular restrictions on that right. We do not believe it would be wise for this court to attempt to identify various combinations of circumstances and interests and attempt to indicate which combinations might and which might not constitutionally permit termination of parental rights.

We will say this much, however: a parent's fundamental right to the companionship of one's child can be significantly eroded by that parent's consent to the surrender of that child. That surrender, if voluntary and knowingly made, may reduce the strength of that fundamental right to the point where a statute awarding custody and all parental rights to the adoptive couple, would be valid.

Further, the threshold of constitutional protection might not be reached if the court held that enforcement of the contract was not even state action under Shelley $v$. Kraemer, 334 U.S. 151, n. 15.

45. Commentary on developments in reproductive technology and the law has sought to distinguish the various conceptual models available for a legislative response. Generally, such attempts have not succeeded in identifying the truly salient differences among approaches. The report of the United States Office of Technology Assessment identifies them as "static, private ordering, inducement, regulatory, and punitive." United States Office of Technology Assessment, Infertility: Medical and Social Choices, (1988), p. 269. The Ontario Law Reform Commission identifies alternatives as "private ordering," "state regulation," and "hybrid" or "flexible." Ontario Law Reform Commission, Report on Human Artificial Reproduction and Related Matters, (1985), p. 130 [hereinafter Ontario Law Reform Commission]. The University of Virginia's Walter Wadlington suggests the following division: (1) static; (2) private ordering; or (3) state regulation. Wadlington, "Artificial Conception: The Challenge for Family Law," 69 U. Va. L. Rev. (1983), pp. 465, 496-97. These schematizations revolve around supposedly germane distinctions between status quo and progress and between government intervention and private choice. There is not space here to develop why these distinctions are less than satisfactory. For an alternate taxonomy, see Wagner, "The Contractual Reallocation of Procreative Resources and Parental Rights: The Natúral Endowment Critique," 40 Case W. Res (1990), p. 1. Suffice it, for the purposes of the present discussion, to say, with respect to the first distinction, that the balance between permanence and change which is always necessary in law is a purely formal dichotomy which has nothing to offer by way of substantive direction, and, with respect to the second, that the distinction between state regulation and private choice does not go deep enough, since both approaches entail the use of governmental coercion against individual claims. 
or reverse the policies on which the New Jersey Court based its decision. These proposals can be classed as falling into four types: (1) prohibition; (2) decommercialization; (3) approval with governmental validation; and (4) approval with "private ordering" validation. The momentary legal stasis centering on In re Baby $M$ can be expected to dissolve and re-form according to one of these four approaches, once the matter has been evaluated or adjudicated by state legislatures, Congress, and the United States Supreme Court.

\section{Four Avatlable Alternatives for Shaping the Legislative RESPONSE TO HIREd MATERNITY}

\section{Prohibition}

An outright prohibition of the alienation of maternity, whether on a commercial or altruistic basis, would fulfill all the concrete policy objectives enumerated above. Without consulting prudential considerations, this option could be viewed as the one to be preferred among those available. Arguably, it could be considered the response the final section of the Vatican Instruction recommends. ${ }^{46}$ The option has analogies in the existing criminal prohibitions still to be found in many jurisdictions against bigamy, adultery, fornication, and sodomy. ${ }^{47}$

The Catholic view of civil law does not require such a strong response. The civil law trend is against such prohibitions in other areas of sex-related conduct. Outright prohibition would tend to offend contemporary American sensibilities about personal freedom and privacy. Practically speaking, the ban would be virtually unenforceable. ${ }^{48}$ This option stands little chance of being adopted in any American jurisdiction. Even if it were so enacted, it might well be overturned by the United States Supreme Court.

46. "Legislation must also prohibit, by virtue of the support which is due to the family ... 'surrogate motherhood'." Vatican Instruction, p. 20.

47. See Model Penal Code and Commentaries, Part II (1980), p. 430. The constitutionality of such laws was upheld over arguments that they were invalid in view of the procreative liberty espoused in Roe v. Wade, 410 U.S. 113 (1973), and in Bowers v. Hardwick, 106 S. Ct. 2841 (1986).

48. In Maryland, for instance, S.B. 795 (sponsored by State Senator Stone prior to June 1988) and S.B. 613 (sponsored by State Senator Mitchell prior to June 1987) were apparently general prohibitions that died without legislative enactment. National Committee for Adoption, 1988 State Legislative Activity Regarding "Surrogate Parenting" (June 1988); National Committee for Adoption, 1987 State Legislative Activity Regarding "Surrogate Parenting" (June 1987). 


\section{DeCOMMERCLALIZATION}

The weak form of decommercialization is seen in the responses to hired maternity of such jurisdictions as Louisiana and Nebraska. ${ }^{49}$ Its typical effect is to make contracts alienating maternity void and unenforceable. Some proposals are varied to make such contracts merely voidable at the instance of the gestational mother. ${ }^{50}$ Commissioning parties are, in either case, denied certainty and predictability, since they are denied legal enforcement of the expectancy created by the gestational mother's promise to perform. There can be little question that such a measure would discourage the market for alienated maternity and significantly reduce the incidence of the practice. Importantly, it would also withhold at least some measure of symbolic approval that would otherwise flow from the legal enforcement of the contract.

Under this approach, some hired maternity transactions would continue to go forward, and some money would regularly be exchanged for children and for the termination of parental rights. In cases involving no appearance of legally coerced performance, such transactions could be viewed as implicitly validated by the state since the state would do nothing to suppress them, notwithstanding its parens patriae responsibility for the welfare of children. In the long run, decommercialization in its weak form is likely to evolve further and to become decommercialization in its strong form or to unravel and become outright approval. The weak form of decommercialization probably does not present a stable option.

Like the typical weak-form version of decommercialization, the strong form makes hired maternity contracts void and unenforceable. But, unlike the weak, the strong prohibits even the voluntary exchange of monetary compensation for the contemporaneous alienation of maternity, and it adds significant criminal penalties for attempting to enter or broker such contracts on a commercial basis. This legislative option does not prohibit the alienation of maternity on an altruistic basis, nor does it attempt to limit human conception to the confines of marriage. Still, it does more than merely passively withhold state enforcement from private contract, actively imposing negative sanctions for attempts to commercialize human reproduction. The

49. Nebraska Legislative Bill No. 674 (July 8, 1988); Louisiana Act No. 583 (R.S. 2713) (Sept. 1, 1987).

50. This approach is reflected, for example, in the judicial holding of Surrogate Parenting Associates, Inc. v. Commonwealth of Kentucky ex rel. Armstrong, 704 S.W.2d 209, 213 (1986). 
option appears to offer a workable middle ground avoiding what some might perceive as undue conflict with personal privacy, while nonetheless drawing a bright line between the sphere of market transactions and that of those intimate relationships necessary to the nurturance and dignity of human persons.

The Michigan law on hired maternity is an example of the strong form of decommercialization. ${ }^{51}$ Its enactment appears to represent the best available legal response to hired maternity, when measured against the generic goals appropriate to lawmaking considered above. It incidentally appears to satisfy the essential legislative recommendation on hired maternity found in the Vatican Instruction..$^{52}$

\section{Approval with Governmental Validation}

A third option for responding to hired maternity is approval with governmental validation. For an example of this option, one can turn to a recent uniform statute, promulgated by the National Conference of Commissioners on Uniform State Laws, which, in the first of two alternate suggested forms, institutionalizes the commercial alienation of maternity. The title of the statute is the Uniform Status of Children of Assisted Conception Act [hereinafter Uniform Act]. ${ }^{53}$ The relevant alternate form is entitled "Alternate A." ${ }^{54}$ In contrast to any of the three particular approaches mentioned so farprohibition, and the weak or strong forms of decommercializationall of which are at least arguably acceptable from the ethical perspective

51. Sections 1-13 of P.A. 199 of Michigan Public Acts of 1988. The same approach is seen in the report of the New York State Cuomo Commission. See Proposed Surrogate Parenting Act, in The New York State Task Force on Life and the Law, Surrogate Parenting: Analysis and Recommendations for Public Policy A$I$ (1988). It is also evident in the federal legislation sponsored in 1987 by Rep. Thomas Luken. H.R. 4233, 100th Cong., 1st Sess. (May 14, 1987).

52. Whether my recommendation fulfills the recommendation of the Vatican Instruction depends, in part, on what its drafters meant by "prohibit." The Vatican Instruction does concede that "[the civil law] must sometimes tolerate, for the sake of public order, things that it cannot forbid without a greater evil resulting." Vatican Instruction, p. 20. This would seem to be a basis for moderating the measure of prohibition in the present context. Whether my recommendation fulfills the directive may also be made to turn on the definition of "surrogate motherhood," a term the Vatican Instruction uses but never defines. If the Vatican Instruction means "commercial surrogacy" or "hired maternity" in a strict sense, then the recommendation made here is in full accord with the directive.

53. National Conference of Commissioners on Uniform State Laws, Uniform Status of Children of Assisted Conception Act (typescript and without prefatory note and comments) (approved and recommended for enactment in all the states, Aug. 1988) [hereinafter Uniform Act].

54. Ibid., pp. 3-9. 
delineated in the earlier sections of this article, the Conference of Commissioners' approach is morally unacceptable.

The Uniform Act essentially adopts the scheme developed in about half of the American states over the past thirty years for dealing with Artificial Insemination by Donor (AID)..$^{55}$ Its underlying premises are that parentage can be grounded apart from genetic contribution and can be made to devolve from governmental conferral. The application of this framework in the setting of hired maternity follows the recommendation of the Ontario Law Reform Commission. ${ }^{56}$ Its extension to cover the legal implications of the gestational role makes governmental conferral even more unambiguously the source of parental rights, than do existing enactments on AID.

The Uniform Act requires judicial approval of the hired maternity contract in advance of conception. ${ }^{57}$ Once the contract has been approved and conception occurs, and as long as the gestational mother fails to exercise a limited right to terminate the agreement, the commissioning couple is irrevocably granted parental rights in the child conceived. ${ }^{58}$ Notwithstanding her lack of genetic, gestational, or nurturing relationship with the child at the time of the grant, the wife of the genetic father of the child is equally vested with such rights. They are acquired well in advance of childbirth and, thus, suffice to override the wishes of the gestational mother, even while she continues in a de facto relationship of nurturance with the child in her womb.

Although concern for the welfare of the adult parties and the child in prospect may explain the Conference's requirement of advance judicial validation of the contract, its unfortunate consequence is further to accentuate governmental conferral as the basis of parental rights. The status conferred includes not just that of parenthood, but also that of "surrogate" and even "nonparent." 59 Under the

55. E.g., Unif. Parentage Act, Sect. 5, 9A U.L.A. 592-93 (1979). For suggested relevance of this AID approach to other reproductive technologies, see Krause, "Artificial Conception: Legislative Approaches," 19 Fam. Law. Q. (1985), pp. 185, 194. For a critique of the approach, see Annas, "Fathers Anonymous: Beyond the Best Interests of the Sperm Donor," 14 Fam. Law. Q. (1980), p. 1.

56. Ontario Law Reform Commission, pp. 3-4.

57. Uniform Act., pp. 3-4.

58. Ibid., pp. 7,8 .

59. The Uniform Act provides that a "donor is not the parent of a child conceived through assisted conception," p. 2, "a person who dies before a conception using his sperm or her egg is not a parent of any resulting child born of the conception," Ibid., and "the surrogate and her husband, if any, are not parents ...." p. 8. 
scheme envisioned, some number of women are officially approved by the state as "surrogates" and their relationships, as such, with sperm donors or sperm owners are officially formalized. ${ }^{60}$ At the same time, these women are negatively defined under law, as the "nonparents" of the children they bear. In effect, this legislation modifies American marriage law to encompass not only marriage as it has existed under received law, but also a subordinate form of "marriage" with the content of reproductive concubinage. The Uniform Act represents a radical revision of American marriage and family law.

The Conference gives the gestational mother a right to terminate the contractual relationship up until roughly six months of gestation. ${ }^{61}$ While they intend this provision to mitigate the objectification or reification of the gestational mother that would be incurred through the involuntary enforcement of the contract, the provision actually further underscores conferral by the state as the basis of parental rights. Ostensibly, the six-months cutoff flows from a corresponding legal right the gestational mother presumably has under Roe $v$. Wade to abort a baby up until six months gestation, notwithstanding a contrary prior contractual promise by her. ${ }^{62}$ The Conference appears to see a shelter for the right to preserve parental rights in the mother's nearly absolute right under existing law to decide the survival of the

60. "A surrogate who has provided the egg for the assisted conception pursuant to an approved agreement may terminate the agreement by filing written notice with the court within 180 days after the last insemination pursuant to the agreement. Upon finding . . . that the surrogate has voluntarily terminated the ... agreement ... the court shall vacate the order. . . The surrogate incurs no liability to the intended parents for exercising her right of termination. If the court vacates the order ... the surrogate is the mother of the resulting child, and her husband, if a party to the agreement is the father." Ibid., p. 78.

61. In the draft originally considered by the Conference, as it met to vote on the act, the Comment to the sections on hired maternity noted that "the six-month period was selected to track, as closely as possible, the Supreme Court's decision in Roe v. Wade. Just as a pregnant woman can choose to abort during the first two terms of pregnancy, the statute permits the surrogate to choose to "keep" the child she is bearing during the first six months." National Conference of Commissioners on Uniform State Laws, Status of Children of the New Biology (draft for approval) (July 1988), p. 10.

62. The act provides that "adequate provision must be made" under the contract for "all reasonable health care costs associated with the surrogacy" and that "unless otherwise provided in the surrogacy agreement, all court costs, counsel fees, and other costs and expenses associated with the hearing shall be assessed against the intended parents." Uniform Act, pp. 5-6. The statute does not prohibit additional fees beyond these mandatory costs. 
fetus during the first six months of gestation. Yet, the deadline for the exercise of the abortion right, no less than the deadline for the exercise of the right to revoke waiver of parental rights under the uniform law's hired maternity provisions, exists strictly as a matter of governmental conferral.

The Uniform Act sets the coercive force of law against the natural bond which the gestational mother may come to recognize as morally normative during the crucial third trimester of pregnancy, a period which includes the most vigorous and conscious bodily interaction between mother and child prior to birth and which also represents the most socially manifest phase of pregnancy, since at this stage the expectant mother's condition is readily apparent to those about her. Similarly, the maternal-infant relationship is made void of normative significance as a matter of law at a point prior to childbirth, a potentially life-threatening event that offers profoundly interpersonal, reciprocally traumatic, if on balance gratifying contact between mother and child generally conducive of bonding. Finally, the mother is deprived of the perspective of a return to postpartum hormonal and physical equilibrium from which to assess her own wishes regarding her relationship with this irreplaceable child whom she had not encountered ex utero at the time the court approved the contract.

The Uniform Act permits the payment of money for the right to rear a child and the receipt of the same for the termination of parental rights. The judicial control which the Uniform Act mandates for such transactions may constitute implicit recognition that such exchanges are a threat to the dignity and well being of children and others. But it merely elevates the authority of the state, without succeeding in securing the dignity of human persons. To the contrary, the statute implicitly rejects the inherent dignity of the person and of basic human relationships and substitutes valuations contingent on positive conferral by the state.

When informed international opinion is consulted, the Commissioners' approach would appear to have little chance of achieving enactment, for the present, anywhere other than in North America. ${ }^{63}$ In Canada and the United States, this and other serious proposals of the kind have been advanced. If they are adopted in these North American countries, they might, in view of the influence of North American culture eventually find a reception elsewhere.

63. See e.g., Department of Health \& Social Security (U.K.), Report of the Committee of Inquiry into Human Fertilization and Embryology (M. Warnock Chair) (1984), p. 47. 
Considering the stature of the National Conference of Commissioners and the purely technical appeal of the Conference's legal drafting, the Uniform Status of Children of Assisted Conception Act stands as perhaps the most serious risk of an ethically flawed legislative response to hired maternity.

\section{Approval with Validation by Private Ordering}

In its extreme form, the legal option of approving hired maternity based on a validation in "private ordering," as recommended by commentators like Judge Posner of the United States Seventh Circuit Court of Appeals ${ }^{64}$ and the University of Texas' Professor John Robertson, ${ }^{65}$ appears to call for free alienation, by contract, of virtually all aspects of parental rights, at least up through birth. Whether based on the model of abortion rights as in Robertson, or law and economics as in Posner, this approach, in theory, supplants the family with shifting, legally enforceable contract relationships. Contractual intention replaces nature as the source of rights and duties. Under this option the family dissolves into the marketplace of atomistic individuals. Although often overlooked by proponents, a necessary corollary of the approach is that persons be treated as property, whether as raw materials or finished product. The enactment of this extreme form of the option appears unlikely at present.

The private ordering option exists as well in a more moderate form, which does not subject family ties to untrammeled market exchanges, but allows the market to operate only to a restricted degree. Such moderate forms of the private ordering option, still objectionable from an ethical perspective, stand in some jeopardy of being enacted. An example of this qualified form of private ordering was seen in the proposal promulgated by the American Bar Association Section on Family Law. The ABA Family Law Section's proposal, ultimately rejected by the ABA House of Delegates, was known as the Model Surrogacy Act (Model Act). ${ }^{66}$ This legislative proposal can

64. Posner, "The Ethics and Economics of Enforcing Contracts of Surrogate Motherhood," 5 J. Cont. Health Law \& Pol'y, p. 21; Posner, "The Regulation of the Market in Adoptions," 67 Boston U. L. Rev. (1987), p. 59; Landes \& Posner "The Economics of the Baby Shortage," 7 J. Legal Stud. (1978), p. 323.

65. Robertson, "Embryos, Families, and Procreative Liberty: The Legal Structure of the New Reproduction," 59 S. Cal. L. Rev. (1986), p. 942; Robertson, "Procreative Liberty and the Control of Conception, Pregnancy, and Childbirth," $69 \mathrm{Va}$. L. Rev. (1983), p. 405.

66. Section of Family Law Adoption Committee and Ad Hoc Surrogacy Committee, "Draft ABA Model Surrogacy Act," 22 Fam. Law. Q. (1988), p. 123 
be characterized as private ordering within a consumer protection framework.

The Model Act makes freedom of contract, at least where validated by reference to reproductive choice, its justifying ground. In this respect, the work of John Robertson seems to lend the most plausible theoretical basis for what the Model Act contains. ${ }^{67}$ At the same time, the drafters restrict freedom of contract for certain paternalistic goals. They wish to protect the child in prospect from being reared in an unfit family. ${ }^{68}$ They desire to protect the "surrogate" from uninformed consent, and to provide her with minimal employment conditions and benefits. ${ }^{69}$ They aim to keep the price of "surrogacy" services to an affordable minimum, and to avoid the financial exploitation of the commissioning couple. ${ }^{70}$

[hereinafter Model Act]. The Model Act was approved by the Council of the American Bar Association's Section of Family Law, at its January 1988 meeting. It was rejected by the ABA House of Delegates in February 1989; during the same meeting, the ABA House of Delegates voted to endorse the National Conference of Commissioners' Uniform Act.

67. Section 1 of the Model Act states that its purposes include, among others, to "facilitate private reproductive choices by effectuating the parties' intentions while minimizing the risks to the parties." Ibid., p. 125.

68. The Model Act provides that:

[b]efore the insemination and not more than one year before the insemination, the intended parents shall be examined by a certified or registered social worker who shall obtain a complete social history of the intended parents and determine whether the intended parents appear to be suited to going through the process of having a child through surrogacy and raising a child born of a surrogacy agreement. Ibid., p. 129.

69. The Model Act stipulates that:

[b]efore the insemination and not more than 18 months before the insemination, the surrogate shall be examined by a licensed or registered mental health practitioner.... The licensed or registered mental health practitioner shall examine the surrogate to determine whether, to a reasonable degree of psychiatric or psychological certainty the surrogate . . . is mentally and emotionally capable of entering into a surrogacy agreement. Ibid., p. 128-29.

The Model Act also requires that "[b]efore the insemination the surrogate shall be examined by a certified or registered social worker who shall obtain a complete social history of the prospective surrogate and determine whether the prospective surrogate appears to be suited to being a surrogate." Ibid., p. 129.

70. The Model Act specifies that:

the minimum and maximum fee to be paid to the surrogate shall be determined by an administrative body of three persons, called the ... Surrogacy Fee Agency. The ... Surrogacy Fee Agency shall not set the minimum fee at less than $\$ 7,500$. The maximum fee shall not be more than $\$ 12,500 \ldots$. The surrogacy agreement may, however, waive the payment of a fee ... if the surrogate is related to the intended parents or if [t]hey have known each other for a period of more than three years. ..."

Ibid., p. 125. 
The private ordering provided for under the Model Act is far from a validation of the classic nineteenth century notion of freedom of contract. It represents freedom of contract within the limits of the new feudalism, according to which transactions are mass produced; the level of risk which the parties are permitted to assume is strictly allocated, and entitlements are distributed according to consumer welfare. ${ }^{71}$

Once the gestational mother has entered the "surrogacy" track by being certified as "suited to be a surrogate" and by conceiving a child, this scheme does not prevent her from aborting the baby under a constitutionally recognized abortion right, but it deprives her of any right to change her mind about relinquishing custody of a child born alive. She is subject to the specific enforcement of her promise to deliver her child..$^{72}$ Although the Model Act technically requires that the commissioning parties receive a psychologist's approval before being eligible to rear the resulting child, the fact is inescapable that this scheme makes the baby a fit object of mercantile exchange. ${ }^{73}$ The effect of the Model Act is to commodify women and children. Against this backdrop, the ABA Family Law Section's Model Surrogacy Act's consumer-protection safeguards ring hollow. This draft law is at home in empowering certain classes and subordinating others. It is a cynical and poorly drafted proposal, which, if enacted, would contribute to a grotesquely alienated society.

\section{CONCLUSION}

From the ethical perspective that has been developed here, the practice of hired maternity is, like human slavery, always and everywhere morally objectionable. The viewpoint espoused has been expressly identified as Roman Catholic. Some of its basic terms have been articulated with assistance from the Vatican Instruction on Respect for Human Life in Its Origin and on the Dignity of Procreation. Yet, the perspective advanced is grounded in human reason and is addressed to all in the political community. Ultimately, what this article advocates is not its distinctive ethical methodology,

71. See generally M. Glendon, The New Family and the New Property (1981).

72. If she aborts when not "medically necessary," however, she will be liable to the "intended parents" for money damages. Ibid., p. 133. The Model Act provides that "[a]fter the child is born, either of the parties shall have the right to specific performance, that is, the right to have the court order and enforce the delivery of the child to the intended parent or parents." Ibid., p. 133.

73. For a discussion of the concept of commodification, see Radin "Market Inalienability," 100 Harvard L. Rev. (1987), p. 1849. 


\section{THE AMERICAN JOURNAL OF JURISPRUDENCE (1990)}

but a proposal that the political community join together, from its varied moral perspectives, in adopting a legal response to hired maternity, which preserves the normative value of the human family and of the human person as fundamental to the public order of society, and which otherwise supports a minimal fabric of public morality. 